\title{
ISU STRATEGI PEMBIAYAAN DEFISIT ANGGARAN DI INDONESIA
}

\author{
Daryono Soebagiyo \\ Fakultas Ekonomi Universitas Muhammadiyah Surakarta \\ Jalan A. Yani Tromol Pos I Pabelan Surakarta Telepon +62-0271- 717417 \\ E -mail: daryono51@ymail.com
}

Diterima 21 Januari 2012 / Disetujui 1 September 2012

\begin{abstract}
The issue of budget deficit financing strategy has been broad enough to gain attention in macroeconomic policy. This study is focused on Analysis of Budget Deficit Financing in Indonesia. How is the deficit financing management implemented such as what are the best sources and its contribution to the Indonesian economy. The study explains that the model used to estimate the impact indicators is capable to manage budget deficit financing, in which the variable domestic financing and external debt encourages the economic growth. Another research goal is to identify the amount of deficit financing sources and their effects on the economy. Under normal conditions in simulation 2. by increasing foreign financing about 15 percent, economic growth will increase about 1.40 percent, and inflation will fall about 0.11 . In the crisis where the interest rate increased 15 percent and domestic financing increased with the same rate, economic growth will fall 0.08 and inflation 0.01 percent.
\end{abstract}

Keywords: budget deficit financing, financing sources, domestic financing, debt financing

\begin{abstract}
Abstrak: Isu strategi pembiayaan defisit anggaran mendapatkan perhatian yang cukup luas dalam kebijakan makroekonomi. Strategi pembiayaan defisit anggaran di Indonesia dari waktu ke waktu tidak mengalami perubahan yang signifikan, hal ini dikarenakan setiap negara memiliki cara yang berbeda untuk menyelesaikan permasalahan kebijakan pembiayaan defisit yang dilakukan. Studi ini memfokuskan Analisis Pembiayaan Defisit Anggaran di Indonesia, pengelolaan pembiayaan defisit akan dilihat dari sumber pembiayaan yang terbaik, serta mampu memberikan kontribusi positif terhadap perekonomian. Tujuan penelitian yang lain adalah teridentifikasinya besarnya sumber-sumber pembiayaan defisit dan pengaruhnya terhadap perekonomian. Hasil penelitian model yang dipakai mampu menjelaskan sumber-sumber pembiayaan defisit di Indonesia. Berdasarkan simulasi 2 yang dilakukan, dengan menaikkan pembiayaan luar negeri sebesar 15 persen, maka Pertumbuhan rata-rata akan meningkat 1,40, tingkat inflasi cenderung turun 0,11. Sedangkan pada kondisi krisis, ketika terjadi kenaikan tingkat bunga tahun lalu 15 persen, pembiayaan domestik naik 15 persen, pertumbuhan ekonomi naik 0,08 persen dan inflasi turun 0,01 persen.
\end{abstract}

Kata kunci: pembiayaan defisit anggaran, sumber pembiayaan, pembiayaan domestik, pembiayaan hutang

\section{PENDAHULUAN}

Isu strategi pembiayaan defisit anggaran mendapatkan perhatian yang cukup luas dalam kebijakan makroekonomi sebagai program kebijakan pembangunan ekonomi berkelanjutan.

Mengapa ini penting karena di setiap negara baik negara maju: AS, UK, Jerman, Jepang
Italia, bahkan Cina, Spanyol, Korea, maupun terlebih negara-negara sedang berkembang, seperti: Indonesia akan mengalami persoalan defisit anggaran. Tetapi masing-masing negara memiliki strategi untuk melakukan pembiayaan defisit anggarannya dengan baik, agar pengelolaan pembiayaan bisa optimal.

Kalau diamati dari Tabel 1, tampaknya 
terdapat indikasi bahwa hubungan antara defisit dan pertumbuhan ekonomi seolah tidak ada hubungan. Ada negara-negara yang defisit anggarannya menurun, tetapi pertumbuhannya meningkat, contoh: Jerman, Indonesia, Korea. Tetapi pada kasus: Jepang, Amerika, akan nampak bahwa indikasinya defisit menurun, pertumbuhan ekonominya juga menurun. Sebaliknya untuk kasus lain yaitu: Cina, Spanyol, Italia, dan Inggris, nampak bahwa defisit cenderung meningkat, tetapi pertumbuhan ekonominya juga meningkat. Contoh pada Tabel 1, tampaknya tidak ada pola khusus bahwa dengan meningkatnya defisit akan mengurangi pertumbuhan ekonomi, atau dengan meningkatnya surplus akan meningkatkan pertumbuhan.

Dalam Tabel 1 tampak terdapat indikasi bahwa hubungan antara defisit dan pertumbuhan ekonomi seolah tidak ada hubungan. Terdapat negara-negara yang defisit anggarannya menurun, tetapi pertumbuhannya meningkat, contoh: Jerman, Indonesia, Korea. Tetapi pada kasus: Jepang, Amerika, akan tampak bahwa indikasinya defisit menurun, pertumbuhan ekonominya juga menurun. Sebaliknya untuk kasus lain yaitu: Cina, Spanyol, Italia, dan Inggris, tampak bahwa defisit cenderung meningkat, tetapi pertumbuhan ekonominya juga meningkat. Contoh pada Tabel 1 tampak tidak ada pola khusus dengan meningkatnya defisit akan mengurangi pertumbuhan ekonomi, atau dengan meningkatnya surplus akan meningkatkan pertumbuhan. Maka berdasarkan Tabel 1 mengindikasikan nampaknya seolah-olah tidak ada hubungan secara pasti antara defisit dan pertumbuhan ekonomi. Padahal secara teoritis, defisit lebih mencerminkan pemerintah mengalami ekspansi ada kecenderungan pertumbuhan ekonomi meningkat. Tetapi ketika terdapat surplus lebih mencerminkan kontraksi ekonomi dari sisi pemerintah. padahal harapannya pertumbuhan ekonomi seharusnya turun.

Berdasarkan hasil kenyataan empiris (tabel) dan pertentangan dengan teoritis yang ada, tampaknya permasalahan yang perlu diangkat dalam studi penelitian ini adalah pada permasalahan "pembiayaannya" bukan masalah "defisitnya". Jadi tampaknya yang paling perlu diperhatikan bagaimana cara membiayai defisit anggaran. Itulah yang menjadi fokus penelitian saya.

Bagi negara Indonesia isu defisit anggaran mendapatkan perhatian utama sejak periode Orde Baru. Perhatian ini karena tingkat inflasi cukup tinggi yang disebabkan oleh pembiayaan defisit anggaran melalui cetak uang. Pengalaman waktu itu membuat pemerintah mencoba memperbaiki kembali dengan anggaran berimbang dan dinamis untuk menggantikan anggaran moneter. Anggaran tersebut dibuat dengan tujuan untuk menertibkan defisit anggaran dari hutang luar negeri. Diikutsertakannya hutang luar negeri sebagai sumber penerimaan negara maka anggaran terlihat sebagai

Tabel 1. Hubungan Antara Defisit dan Pertumbuhan Ekonomi

\begin{tabular}{|c|c|c|c|c|}
\hline \multirow[t]{2}{*}{ Negara } & \multicolumn{2}{|c|}{ Defisit/Surplus (Milyar Dollar) } & \multicolumn{2}{|c|}{ Tingkat Pertumbuhan PDB (Persen) } \\
\hline & 2004 & 2008 & 2004 & 2008 \\
\hline \multicolumn{5}{|c|}{ Defisit menurun, pertumbuhan ekonomi meningkat } \\
\hline Germany & -100 & 35 & $-0,1$ & 2,5 \\
\hline Indonesia & $-1,11$ & $-0,5$ & 4,1 & 6,3 \\
\hline South Korea & -5 & 2,3 & 3,1 & 5 \\
\hline \multicolumn{5}{|c|}{ Defisit menurun, pertumbuhan ekonomi menurun } \\
\hline Japan & -348 & -201 & 2,7 & 1,9 \\
\hline US (federal) & -476 & -455 & 3,1 & 2 \\
\hline \multicolumn{5}{|c|}{ Defisit meningkat, pertumbuhan ekonomi meningkat } \\
\hline Cina & -31 & -165 & 9,1 & 11,9 \\
\hline Spain & -2 & $-92,3$ & 2,4 & 3,8 \\
\hline Italy & -52 & -64 & 0,4 & 1,4 \\
\hline Uni. Kingdom & -62 & -135 & 2,2 & 3,1 \\
\hline Perancis & -75 & -216 & 0,5 & 2,1 \\
\hline
\end{tabular}

Data: diolah dan dianalisis dari Sumber World Development Indicators 
balance budget. Tetapi hutang luar negeri ini bukannya tanpa masalah, beban hutang luar negeri yang semakin besar membawa konsekuensi beban anggaran dengan pembayaran pokok serta bunga hutang ikut meningkat.

Data sekunder publikasi Departemen Keuangan Republik Indonesia dalam kurun waktu 2004-2008 pembiayaan defisit menunjukkan pola konsisten, sedangkan pembiayaan dari hutang meningkat secara signifikan. Seperti apa yang tertuang di Gambar 1 menunjukkan terjadinya peningkatan pembiayaan defisit anggaran tiap tahunnya, dan besaran pembiayaan defisit tersebut disesuaikan dengan keadaan perekonomian negara.

Indonesia selalu melaksanakan kebijakan pembiayaan anggaran defisit. Pada masa pemerintahan Orde Baru menggunakan pendekatan konsep anggaran berimbang, namun secara substansi kebijakan pembiayaan anggaran yang ditempuh Indonesia adalah defisit. Pembiayaan defisit anggaran belanja pada masa pemerintahan Orde Baru ditutupi dengan pinjaman luar negeri yang dicatat dalam Anggaran Belanja Negara (APBN) sebagai Penerimaan Pembangunan. Sungguhpun sejak tahun 2000 defisit anggaran ditutupi dengan pinjaman dari dalam negeri dan dari luar negeri.

Strategi pembiayaan defisit anggaran yang dijalankan Indonesia dari waktu ke waktu tidak ada perubahan signifikan, di mana setiap tahun anggaran pilihannya selalu berorientasi pada pembiayaan melalui pinjaman.

Pembiayaan defisit anggaran yang akan diteliti memiliki implikasi terhadap pertumbuhan ekonomi (sektor riil) dan utamanya melalui tingkat inflasi serta variabel lain seperti jumlah uang beredar, tingkat bunga dan kurs mata uang rupiah (dari sektor moneter). Selanjutnya baik implikasi dari sektor riil maupun moneter tersebut akan berpengaruh terhadap perekonomian.

Isu pengelolaan pembiayaan defisit fiskal di mana sumber pembiayaan anggaran terdiri dari: faktor external resources dan faktor internal resources. Bagaimana mengelola sumber pembiayaan, agar diupayakan pembangunan ekonomi yang terbaik, serta untuk memberikan kontribusi terhadap keberlangsungan pembangunan ekonomi. Keberlangsungan ekonomi yang diharapkan adalah untuk stabilisasi Ekonomi dan pertumbuhan ekonomi yang dinamis. Oleh sebab itu sejalan dengan fokus penelitian pada isu pengelolaan pembiayaan, maka rumusan masalah yang penulis ketengahkan di sini adalah; Apakah perbedaan dalam sumber pembiayaan defisit anggaran memiliki dampak yang berbeda terhadap perekonomian. Serta di antara beberapa sumber pembiayaan defisit anggaran tersebut, sumber manakah yang memiliki dampak terbaik bagi perekonomian Indonesia. Sedangkan tujuan penelitian antara

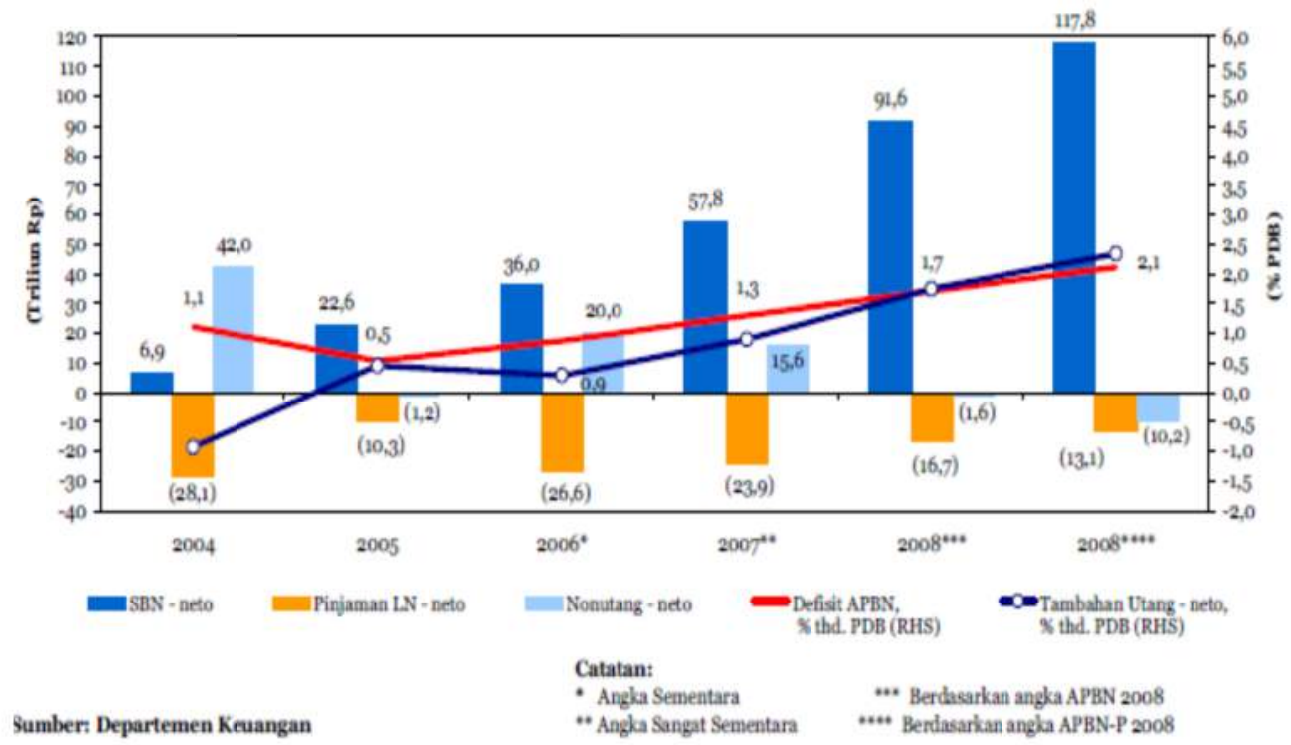

Gambar 1. Perkembangan Pembiayaan Defisit Anggaran dalam Tahun 2004-2008 


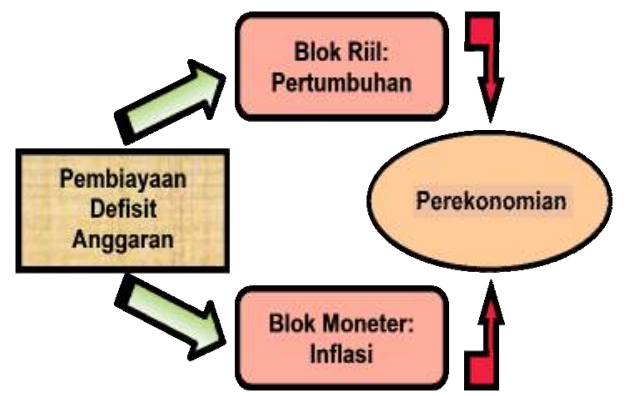

Gambar 2. Kerangka Pikir "Pembiayaan Defisit Anggaran"

lain; Teridentifikasinya dampak masing-masing sumber pembiayaan defisit anggaran terhadap perekonomian. Serta teridentifikasinya sumber pembiayaan yang paling cocok bagi perekonomian Indonesia.

Review Literatur. Pembiayaan defisit anggaran setidaknya dapat untuk mendanai pengeluaran pemerintah agar terjadi peningkatan produktivitas perekonomian, yaitu pengeluaran kapital pemerintah untuk investasi. Dornbusch et al.(1989) membagi dua macam sumber pendanaan defisit anggaran, yaitu hutang bank sentral dan hutang publik. Ketika pemerintah mendanai defisit anggaran dengan meminjam dari masyarakat, pemerintah akan melakukan kebijakan pembiayaan hutang (debt financing). Tetapi menurut Hossain dan Chowdhury (1998) menyatakan bahwa, seperti juga di negaranegara maju, pembiayaan defisit anggaran bagi negara-negara sedang berkembang adalah bagaimana anggaran defisit dapat dibiayai dari setidaknya tiga sumber, yaitu; dengan menjual obligasi ke publik, dengan pinjaman luar negeri, dan dengan mencetak uang atau oleh campuran dari ketiganya. Sedangkan menurut pendapat Turnovsky dan Wohar, (1987) dan Scarth (1988) menyatakan bahwa, sumber pembiayaan defisit anggaran secara konvensional terdiri dari money financed dan bond financed defisit, yaitu pembiayaan dengan pencetakan uang dan pembiayaan dengan menerbitkan bonds atau obligasi negara. Menurut Garcia (1996), secara garis besar ada dua cara pembiayaan defisit yaitu dengan pencetakan uang (money creation) dan hutang (Debt). Bahkan Buiter (1982, 1995) mengidentifikasi sumber pembiayaan defisit berasal dari: 1) hutang luar negeri, 2) hutang dalam negeri, 3) Pencetakan uang, 4) Privati- sasi, 5) Runing down cadangan devisa pemerintah. Masing-masing mekanisme pembiayaan defisit memberikan pengaruh berbeda terhadap perekonomian baik sendiri-sendiri maupun secara bersama-sama.

Pandangan Keynes-Klasik. Pandangan mainstream ekonomi (Klasik maupun Keynesian) menyatakan bahwa tidak pernah ada bicara tentang pembiayaan tetapi yang ada hanya membicarakan expenditure yang setidaknya akan mempengaruhi pertumbuhan perekonomian.

Pandangan Keynesian memposisikan pada government expenditure, di mana pada kondisi krisis, maka defisit diperlukan untuk pertumbuhan ekonomi

Sedang menurut pemikiran Klasik, dalam keseimbangan, maka balanced budget, akan lebih penting. Kalau terjadi defisit maka dengan adanya tambahan uang akan mengakibatkan efek inflasi, ini apabila tidak segera ditindak lanjuti dengan upaya peningkatan di sektor riil yang lebih baik serta pertambahan permintaan masyarakat.

Pandangan Dependensia. Sebaliknya menurut pandangan Dependensia (ekonomi politik) memberikan definisi yang berbeda tentang pembiayaan anggaran, menyatakan keberhasilan negara-negara yang melakukan kebijakan pembiayaannya dengan melakukan pinjaman atau bantuan modal tidak tampak terlihat Frank (1969) dan Santos (1970). Bahwa suatu negara yang tergantung dengan kebijakan pinjaman atau pembiayaan hutang, tidak ada kemungkinan lepas dari ketergantungan ChaseDunn (1982). Bagi pandangan Dependensia akan terjadi ekses dari ketergantungan pada pembiayaan, dan keputusan pemilikan pinjaman sa- 
ngat penting bagi tingkat ketergantungannya

Sedang menurut Coe, Pesaran, Vahey, (2003), melihat bahwa deficit financing, akan terkait dengan persoalan debt managemant yaitu manajemen hutang untuk memastikan pembiayaan kebutuhan pemerintah dan kewajiban pembayaran yang terpenuhi dengan biaya minimal sampai jangka panjang, akan selaras dengan tingkat risiko kebijakan yang dilakukan.

\section{METODE PENELITIAN}

\section{Model dan Data}

Persoalan pembiayaan defisit anggaran bagi Indonesia nampaknya perlu suatu mekanisme pembiayaan defisit yang dipergunakan. Pembiayaan tersebut bisa dilihat dari external resources dan internal resources. Pembiayaan defisit anggaran bagi Indonesia akan dimanfaatkan sebagai upaya untuk pembangunan ekonomi yang berkelanjutan. Oleh sebab itu makna alur mekanisme yang telah dikemukakan di bawah adalah: pembiayaan defisit anggaran akan mempengaruhi sektor riil melalui pasar barang, sedangkan melalui sektor moneter melalui penawaran uang, tingkat inflasi dan tingkat bunga, kurs mata uang rupiah terhadap dolar dan selanjutnya hubungan antara dua pasar, baik, di sektor riil (IS) demikian pula di sektor pasar uang (LM) akan bekerja secara berurutan dan saling mempengaruhi. Beberapa variabel memiliki pengaruh secara timbal balik pada kinerja makroekonomi.

Model yang menjadi dasar studi penelitian ini adalah model yang pernah digunakan oleh Tanuwidjaja dan Meng (2005) yang juga diambil dari fondasi teoritis model yang telah ada sebelumnya yang dikembangkan Batini-Haldane

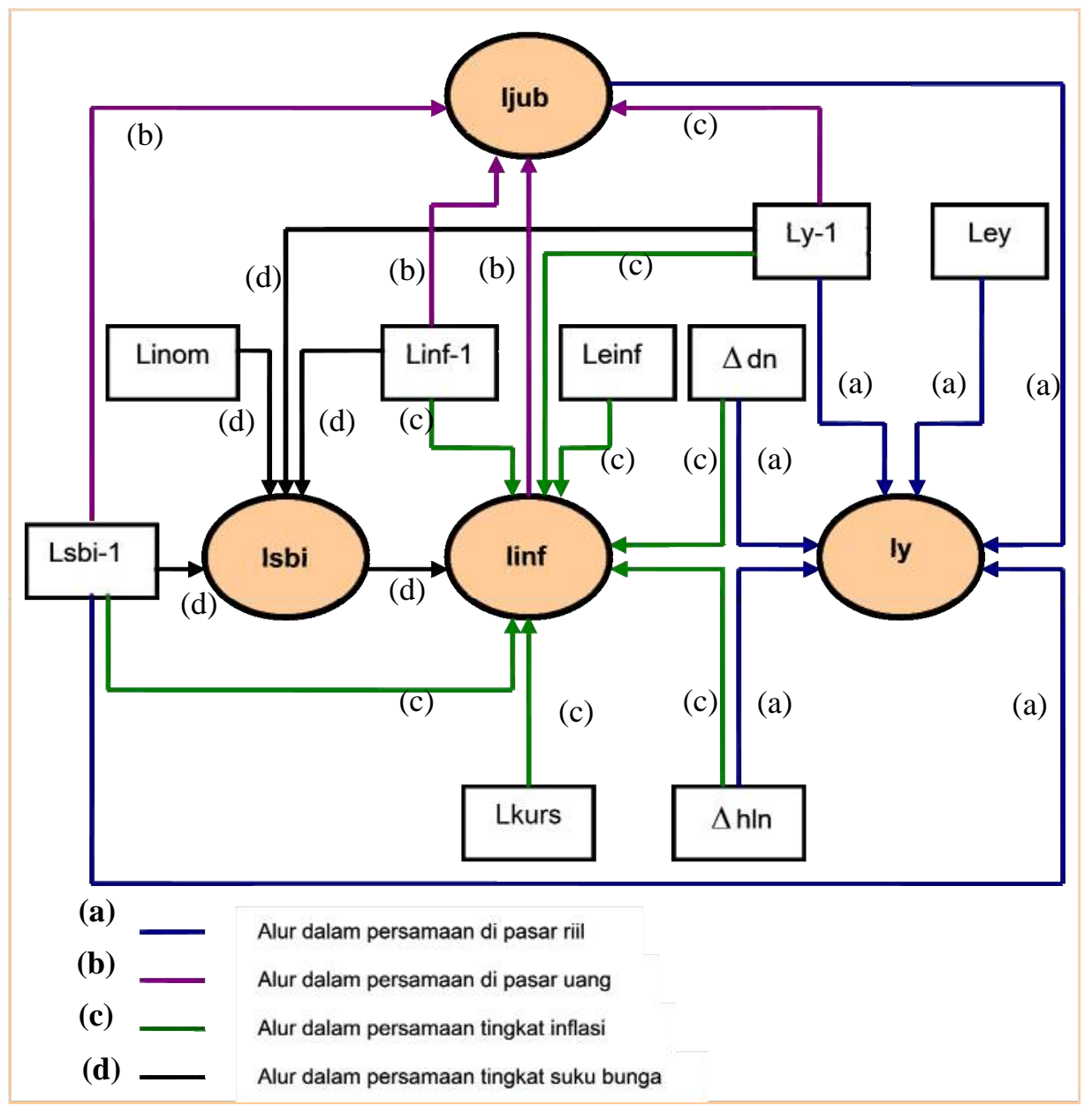


(1999) dengan model berulang (recursive models) serta kuadrat terkecil yang telah dimodifikasi sesuai dengan kebutuhan.

Spesifikasi Model Persamaan. Spesifikasi Model Small Scale macroeconomic Model (SSMM) yang dibentuk dari persamaan pengelolaan pembiayaan defisit anggaran adalah:

Apabila $\Delta \mathrm{G}=\Delta \mathrm{Hln}+\Delta$ dn dan $\Delta$ dn adalah autonomous dari persamaan dasar yang ada, yaitu:

$l y=a_{0} l_{-1}+a_{1} l e y+a_{2} \Delta G+a_{3} l j u b+a_{4} l s b i_{-1}+$ aslinf $+\varepsilon$

Maka, persamaan (1) Sektor Riil adalah sebagai berikut:

ly $=a_{0} l_{-1}+a_{1} l e y+a_{2} \Delta H \ln +a_{3} \Delta d n+a_{4} l j u b$ $+\mathrm{a}_{5} \mathrm{lsbi}_{-1}+\mathrm{a}_{6} \mathrm{linf}+\varepsilon$

Sedang persamaan (2) di pasar uang adalah:

lJub $=$ b $_{1}$ lsbi-1 $_{-1}+b_{2} l_{-1}+b_{3} l_{i n f}+b_{4} l_{i n f}-1 \varepsilon$

Persamaan (3) Tingkat Inflasi

linf $=\gamma_{0}$ leinf $+\gamma_{1 \text { linf }_{-1}+} \gamma_{2 \text { ly }_{-1}}+\gamma_{3}$ lsbi + $\gamma_{4} \mathrm{lsbi}_{-1}+\gamma_{5} \mathrm{dhln}+\gamma_{6} \mathrm{dn} \gamma_{7}+\mathrm{lkurs}+\varepsilon$

Persamaan (4) Tingkat Suku Bunga

lsbi $=\beta_{1 \text { lsbi }_{-1}+} \beta_{2 \text { linom }^{+}} \beta_{3 \text { linf }_{-1}}+\beta_{4 \mathrm{ly}_{-1} \varepsilon}$

Keterangan: e adalah Ekspektasi (Perkiraan $\mathrm{t}+1), \Delta \mathbf{G}$ adalah Government Spending, dn adalah pembiayaan Domestik (Dalam Negeri), Hln adalah Pembiayaan Hutang Luar Negeri, lsbi adalah Suku bunga riil (didekati dengan SBI 3 Bulan), Lsbi(-1) adalah Suku bunga riil lag satu periode tahun lalu, ly adalah PDB Riil, ley adalah ekspektasi PDB riil yaitu $\mathrm{y}_{\mathrm{t}+1}$ dan ly(-1) adalah $\mathrm{y}_{\mathrm{t}-1}$ merupakan lag satu periode (tahun lalu), Iinf adalah Tingkat Inflasi, Iinf(-1) adalah lag inflasi tahun lalu $\mathrm{t}_{-1}$ dan, leinf adalah Ekspektasi inflasi ${ }_{t+1}$, lKurs adalah kurs mata uang $\mathrm{Rp}$ terhadap dollar Amerika, linom adalah tingkat suku bunga nominal, ljub adalah mt-Pt didekati dari JUB riil.

Penjabaran variabel-variabel operasionalnya yang disertakan dalam model persamaan SSMM adalah sebagai berikut:

(1) Defisit Anggaran (G) terjadi karena nilai pengeluaran (belanja) negara lebih besar dari penerimaannya. Defisit anggaran yang terjadi dalam anggaran APBN indonesia adalah: Defisit primer $=(R+A)-(G-B)$ di mana $R$ adalah total penerimaan pemerintah, $\mathrm{A}$ adalah total hibah, $G$ pengeluaran rutin (Dalam negeri + Luar negeri) dan B pembayaran bunga dan hutang. satuannya rupiah, data didapatkan dari BPS maupun departemen keuangan.

(2) Inflasi (Inf) adalah merupakan suatu nilai di mana tingkat harga barang dan jasa secara umum mengalami peningkatan, adalah salah satu fenomena moneter yang menunjukkan suatu kecenderungan akan naiknya harga barang-barang secara umum, yang berarti adanya penurunan nilai uang. Dalam penelitian ini nilai inflasi akan didekati melalui inflasi dalam negeri yang sepenuhnya dikontrol oleh kebijakan moneter yang diukur dalam persen, yaitu IHK yang telah direduksi dari pengaruh noise yang bersumber dari guncangan sisi penawaran. Data inflasi inti merupakan data tahunan dalam rentang periode tahun 19832009. Data tersebut diperoleh dari: BPS, Laporan Tahunan BI berbagai edisi penerbitan. Ekspektasi dari nilai inflasi (e) adalah $\pi_{t+1}$ dalam persen, di mana data didapatkan dari nilai inflasi tiap tahun yang dipublikasikan BPS, Statistik Keuangan BI, maupun dalam Nota Keuangan Depkeu.

(3) Pertumbuhan (y). Adalah PDB (Produk Domestik Bruto), yaitu besarnya nilai Produk Domestik Bruto berdasarkan harga konstan tahun 2000, satuannya adalah rupiah, di mana pendapatan akan didekati melalui komponen PDB. Data $Y_{t}$ atau PDB merupakan data tahunan dalam periode tahun 1983 sampai tahun 2009, dengan satuan rupiah diperoleh dari International Financial Statistics (IFS) Laporan Tahunan Bank Indonesia dan BPS serta SEKI.

(4) Pembiayaan Domestik (dn) adalah merupakan besarnya total hutang pemerintah, yang dibiayai dari domestik atau dalam negeri, satuannya rupiah data tahunan, akan didapat dari publikasi BPS maupun dari Nota Keuangan Depkeu.

(5) Belanja pemerintah merupakan total dari nilai pengeluaran (belanja) pemerintah ber- 
dasarkan APBN dengan data tahunan, dalam satuan rupiah. Didapat dari publikasi Nota Keuangan Depkeu.

(6) Pembiayaan Hutang Luar Negeri (Hln) merupakan besarnya total hutang pemerintah, yang dibiayai dari luar negeri, satuannya rupiah. Pembiayaan melalui pinjaman (hutang) pemerintah di mana besarnya hutang pemerintah berpengaruh positif terhadap pembayaran cicilan hutang luar negeri. Semakin besar hutang pemerintah akan semakin besar pembayaran cicilan hutang luar negeri. Defisit anggaran berpengaruh positif terhadap besarnya hutang yang dilakukan oleh pemerintah. Semakin besar defisit anggaran maka akan semakin besar hutang luar negeri yang dipinjam pemerintah (Kunarjo, 1997). Data tahunan, diperoleh dari: Laporan Tahunan Bank Indonesia dan BPS, serta Departemen Keuangan.

(7) Money supply dan money demand didekati melalui besarnya JUB, yaitu jumlah uang beredar, satuannya adalah rupiah. Data diperoleh dari, Laporan Tahunan Bank Indonesia dan BPS, serta Depkeu.

(8) Suku bunga SBI (sbi) suku bunga Sertifikat Bank Indonesia, merupakan salah satu indikator kebijakan moneter di Indonesia, yaitu tingkat suku bunga yang secara konsep diukur pengembaliannya setelah dikurangi inflasi, didekati melalui nilai suku bunga SBI 3 bulan, data dari Bank Indonesia, diukur dalam satuan persen.

(9) Suku bunga nominal (inom) adalah Nilai suku bunga nominal, merupakan suku bunga yang dapat diamati dipasaran, didapatkan dari data International Financial Statistics (IFS) diukur dalam satuan persen.

(10) Nilai Tukar (Kurs), adalah merupakan harga relatip nilai tukar mata uang suatu negara (Indonesia), terhadap nilai tukar negara lain, data didapatkan dari publikasi BPS, Statistik Keuangan BI.

\section{Metode Analisis}

Metode analisis yang digunakan dalam penelitian ini adalah analisis deskriptif dan kuantitatif dengan Simultaneous Equation Regression Model adalah model regresi persamaan simultan, merupakan sebuah model persamaan re- gresi yang melihat hubungan bilateral, atau umpan balik antara variabel dependen dan variabel bebas atau independen (Gujarati, 2007). Model-model regresi di mana terdapat lebih dari satu persamaan dan memiliki hubungan umpan balik di antara variabel dikenal sebagai model regresi persamaan simultan (simultaneous equation regression models).

Tahapan dalam melakukan analisis kuantitatif di penelitian ini terdiri dari pembentukan model dasar, uji perilaku data (stasionaritas dan kointegrasi). Spesifikasi model menggunakan Small Scale Macroeconomic Model (SSMM), sedangkan pengumpulan data melalui Data sekunder dan mempunyai sifat berkala dari publikasi International Financial Statistics, Departemen Keuangan, Statistik Keuangan BI serta BPS, dari tahun 1983 sampai tahun 2009.

Lokasi dan obyek penelitian di Indonesia, sedangkan teknik analisis data dengan menggunakan data time series. Sebelum melakukan uji $3 S L S$ maka terlebih dahulu akan dilakukan uji ECT dan ECM untuk Stasioner dan kointegrasi (untuk keseimbangan jangka pendek dan jangka panjang).

\section{HASIL DAN PEMBAHASAN}

Kebutuhan pembiayaan anggaran dalam kurun waktu selama studi penelitian yang dilakukan nampak cenderung meningkat seiring dengan meningkatnya defisit anggaran dan makin besarnya kebutuhan pengeluaran pembiayaan. Kebutuhan pembiayaan anggaran tersebut dipenuhi, baik dari sumber pembiayaan hutang maupun pembiayaan lainnya. Pemenuhan pembiayaan defisit anggaran pada dasarnya merupakan bagian integral dari kebijakan anggaran sebagai bagian dari kebijakan pengelolaan ekonomi makro keseluruhan. Oleh sebab itu, isu pembiayaan defisit anggaran sangat tergantung pada mekanisme pembiayaan defisit yang digunakan.

Pembiayaan anggaran terdiri dari external resources dan internal resources. Pembiayaan defisit anggaran tersebut digunakan sebagai upaya bagi keberlangsungan pembangunan ekonomi. Mengingat sebagian besar sumber pem- 
biayaan anggaran berasal dari hutang, maka pengelolaan dan perencanaan anggaran yang tepat dan akurat menjadi hal yang penting, agar pengelolaan anggaran bisa semakin efisien, dan tidak membebani anggaran pada masa yang akan datang.

Dari hasil studi yang dilakukan sesuai alur mekanisme model, maka di bawah, dapat diketengahkan makna inti persoalannya yaitu: pembiayaan defisit anggaran akan mempengaruhi sektor riil melalui pasar barang, sedangkan melalui sektor moneter melalui tingkat inflasi, penawaran uang dan tingkat bunga, kurs mata uang rupiah terhadap dolar, dan selanjutnya hubungan antara dua pasar, baik di sektor riil (IS) demikian pula di sektor pasar uang (LM) akan bekerja secara berurutan dan saling mempengaruhi. Beberapa variabel memiliki pengaruh secara timbal balik pada kinerja perekonomian.

\section{Hasil Estimasi Uji Stasionaritas dan Kointegrasi}

Sebagaimana langkah dalam uji statistik ekonometrik, pengujian awal dalam data time series ini adalah untuk mendapatkan data runtut waktu yang stationer Gujarati (2003), Greene (2007) memberikan ulasan pernyataannya bahwa untuk menjalankan penelitian yang menggunakan model serta hubungan fungsi maka dapat menggunakan uji kointegrasi EngleGranger.

Analisis uji kointegrasi dilakukan untuk mengetahui adanya keseimbangan yang dicapai dalam jangka panjang, sedangkan ECM (Error Correction Mechanism) untuk mengoreksi ketidakseimbangan dalam jangka pendek (yang mungkin terjadi) menuju keseimbangan jangka panjang.

Dalam penelitian ini uji kointegrasi dilakukan untuk 4 persamaan dalam model, yaitu: model persamaan pasar riil (IS), Model persamaan pasar uang (LM), model persamaan Inflasi, serta model persamaan suku bunga.

Tabel 2 adalah hasil pengujian ECM jangka pendek dengan program eviews berdasarkan pendekatan Engle Granger. Uji analisis model ECM dapat digunakan dalam mengestimasi faktor-faktor dalam pembiayaan defisit anggaran di Indonesia selama periode penelitian dan spesifikasi model yang digunakan adalah sahih atau valid.

Hasil pengujian menunjukkan bahwa ke 4 buah model persamaan memenuhi persyaratan terintegrasi dengan dihasilkannya nilai ECT (Error Corection Terms) bertanda negatif (-), sedangkan hasil pengujian kointergrasi menunjukkan beberapa variabel persamaan probabilitasnya signifikan. Sehingga dapat dikatakan bahwa data series yang dipergunakan adalah stationer, dengan demikian uji analisis ini menghasilkan estimasi yang tidak menyesatkan, maka untuk melakukan estimasi selanjutnya dapat diperbolehkan menggunakan 3SLS.

\section{Hasil Estimasi Model Persamaan 3SLS}

Persamaan simultan dinamis dalam penelitian ini adalah overidentified. Persamaan overidentified dapat diselesaikan dengan 2SLS dan atau 3SLS. 2SLS dan atau 3SLS yang merupakan metode persamaan tunggal dengan adanya korelasi antara variabel-variabel gangguan dan variabel-variabel bebas. Sehingga dengan teknik OLS dapat diterapkan pada persamaan struktural secara terpisah, maka dengan demikian bias simultan dapat dihilangkan. Hasil lengkap regresi $3 S L S$ dapat dilihat pada Tabel 3.

Teridentifikasinya Dampak Masing-masing Sumber Pembiayaan Defisit Anggaran terhadap Perekonomian

Tabel 2. Hasil Uji Kointegrasi dalam Pembiayaan Defisit Anggaran dengan Metode Engle Granger

\begin{tabular}{clcccc}
\hline No. & Persamaan & Variabel Independent & Coefficient & t-Statistic & Prob. \\
\hline 1 & Persamaan Pasar Riil (IS) & ECT & $-0,035358$ & $-0,116712$ & 0,1085 \\
2 & Persamaan pasar uang (LM) & ECT & $-0,024948$ & $-0,104500$ & 0,0179 \\
3 & Persamaan Inflasi & ECT & $-0,013777$ & $-0,039967$ & 0,0686 \\
4 & Persamaan Suku Bunga & ECT & $-0,312346$ & $-1,525782$ & 0,1035 \\
\hline
\end{tabular}

Sumber: data Sekunder yang telah diolah 
Tabel 3. Hasil Regresi dengan Persamaan Simultan 3SLS

\begin{tabular}{|c|c|c|c|c|}
\hline No. & Jenis Persamaan & Nama Variabel & Coefficient & Prob. \\
\hline \multirow[t]{8}{*}{1.} & ly & Persamaan Pasar Riil & & \\
\hline & ly1 & Lag satu periode & 0,24835 & 0,093 \\
\hline & ley & Lead satu periode & 0,18948 & 0,050 \\
\hline & dhln & Pembiayaan Luar Negeri & 0,000006 & 0,833 \\
\hline & $\mathrm{dn}$ & Pembiayaan domestik & 0,00005 & 0,068 \\
\hline & ljub & Jumlah Uang Beredar & 0,18135 & 0,001 \\
\hline & lsbi1 & Lag suku bunga SBI & $-0,14034$ & 0,000 \\
\hline & $\operatorname{linf}$ & Tingkat inflasi & $-0,03986$ & 0,015 \\
\hline \multirow[t]{5}{*}{2.} & ljub & Persamaan Pasar Uang (LM) & & \\
\hline & lsbi1 & Lag Suku bunga SBI 3 bulan & 0,54525 & 0,059 \\
\hline & ly1 & Lag satu periode pertumbuhan. & 2,93190 & 0,000 \\
\hline & $\operatorname{linf}$ & Tingkat inflasi & 0,04102 & 0,765 \\
\hline & $\operatorname{linf1}$ & Lag satu tingkat inflasi & 0,00186 & 0,989 \\
\hline \multirow[t]{9}{*}{3.} & $\operatorname{linf}$ & Persamaan Tingkat inflasi & & \\
\hline & leinf & Lead inflasi satu periode & $-0,24887$ & 0,001 \\
\hline & linf1 & Lag inflasi satu periode & $-0,32386$ & 0,002 \\
\hline & ly1 & Lag pertumbuhan satu periode & 0,65845 & 0,020 \\
\hline & lsbi & Suku bunga SBI 3 bulan & 1,37695 & 0,000 \\
\hline & lsbi1 & Lag SBI satu periode & $-0,53931$ & 0,013 \\
\hline & dhln & Pembiayaan Luar Negeri & 0,00040 & 0,036 \\
\hline & $\mathrm{dn}$ & Pembiayaan Domestik & $-0,00165$ & 0,444 \\
\hline & lkurs & Kurs rupiah terhadap dolar AS & 0,02688 & 0,817 \\
\hline \multirow[t]{5}{*}{4.} & lsbi & Persamaan tingkat Bunga & & \\
\hline & lsbi1 & Lag tngkt bunga SBI satu periode & $-0,38308$ & 0,008 \\
\hline & linom & Suku bunga nominal di pasaran & 1,06699 & 0,000 \\
\hline & linf1 & Lag tingkat inflasi satu periode & $-0,04336$ & 0,506 \\
\hline & lyl & Lag pertumbuhan satu periode & 0,06417 & 0,485 \\
\hline
\end{tabular}

Sumber: Data penghitungan dengan Stata diolah dari data sekunder

Dalam peneltian ini data yang dipergunakan adalah dengan mempergunakan data runtut waktu (time series) dari tahun 1983 sampai dengan tahun 2009. Adapun hasil penghitungan melalui simulasi analisis keterkaitan hubungan sektor fiskal dan moneter pada pembiayaan defisit anggaran terhadap pertumbuhan ekonomi memberikan interpretasi ekonomi dari beberapa alternatif kemungkinan untuk melihat keterkaitan hubungan sektor fiskal dan moneter pada pembiayaan defisit anggaran terhadap pertumbuhan ekonomi (Lihat Gambar 4).

Setelah dilakukan simulasi melalui analisis penghitungan, maka di temukan terdapat beberapa alternatif kemungkinan untuk melihat keterkaitan hubungan sektor fiskal dan moneter pada pembiayaan defisit anggaran terhadap pertumbuhan ekonomi.

\section{Hasil Interpretasi Pembiayaan}

Dengan terjadinya pengaruh terhadap pertumbuhan ekonomi dari 2 kemungkinan maka im- plikasinya terhadap pembiayaan anggaran akan dimungkinkan bahwa:

(1) Adanya peningkatan pada pembiayaan domestik mengakibatkan pertumbuhan ekonomi juga akan mengalami peningkatan

(2) Peningkatan pembiayaan hutang luar negeri, akan mengakibatkan terjadinya kenaikan tingkat inflasi, yang selanjutnya, melalui kenaikan tingkat inflasi tersebut mengakibatkan kecenderungan pertumbuhan ekonomi mengalami penurunan.

(1) Pembiayaan Domestik (Dalam Negeri). Komponen faktor penerimaan pemerintah (G) yang didekati melalui indikator variabel, pembiayaan domestik atau (dn). Pembiayaan domestik secara uji ekonometrik memiliki pengaruh positif adan signifikan, artinya apabila dimungkinkan terjadinya perubahan pertumbuhan pembiayaan domestik (dn), maka akan memiliki implikasi kaitan terhadap peningkatan pertumbuhan ekonomi yang terjadi. Pembia- 


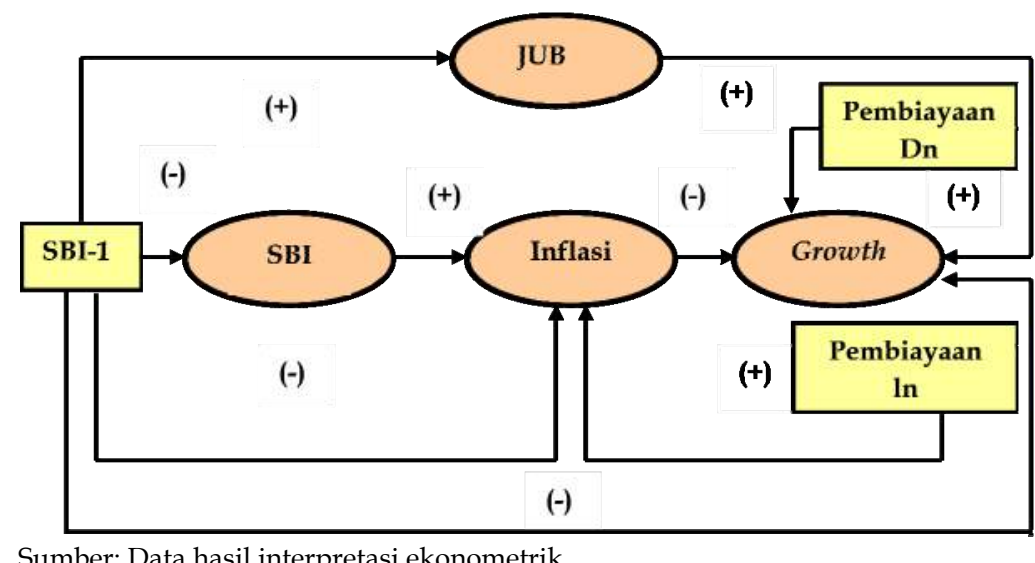

Gambar 4. Keterkaitan Sumber Pembiayaan Terhadap Perekonomian

yaan domestik (dn), adalah merupakan komponen dominan dalam pembiayaan anggaran pemerintah yang masih cukup potensial untuk menanggulangi terjadinya defisit anggaran,

Besarnya defisit anggaran pemerintah merupakan pengurangan antara total penerimaan pemerintah (GR) dengan total pengeluaran pemerintah (GE). Komponen yang mempengaruhi besarnya penerimaan pemerintah dibedakan menjadi dua yaitu: penerimaan pajak dan penerimaan non pajak. Besarnya penerimaan pajak dipengaruhi oleh usaha pemerintah untuk memungut pajak (tax effort).

Jadi dari kebijakan fiskal terlihat bahwa pemerintah perlu melakukan intensifikasi dan ekstensifikasi pemungutan pajak. Salah satu kebijakan intensifikasi perpajakan bisa berupa perbaikan birokrasi pemungutan pajak. Dilihat dari sisi intensifikasi pajak, tidak perlu dikhawatirkan akan memberikan dampak pada penurunan pertumbuhan, karena intensifikasi pajak yang terjadi akan berimplikasi pada daya beli masyarakat. Ketika terjadi intensifikasi pajak, maka daya beli masyarakat yang menurun tidak perlu dikhawatirkan. Karena ini dimungkinkan akan keluar kembali dalam bentuk expenditure, dan terjadinya expenditure akan mengakibatkan terjadinya dorongan terhadap pertumbuhan ekonomi. Pada sisi persoalan lain dengan adanya kenaikan pajak yang terjadi, tidak perlu dikhawatirkan akan mengakibatkan ekonomi mengalami kontraksi (penurunan pertumbuhan ekonomi). Jadi selama terdapat expenditure cukup produktif, maka adanya kenaikan pajak tidak akan memberikan dampak berarti terhadap pertumbuhan ekonomi.

Sedangkan kebijakan ekstensifikasi perpajakan dapat berupa penentuan basis pajak baru dan peningkatan rate pajak. Semakin meningkatnya pertumbuhan ekonomi maka diharapkan akan meningkatkan basis pajak baru, sehingga akan memberikan keleluasaan bagi pemerintah untuk meningkatkan penerimaan pajaknya. Kenaikan penerimaan pajak pada akhirnya akan meningkatkan pertumbuhan ekonomi.

(2) Pembiayaan Hutang Luar Negeri. Hasil dari analisis yang didapatkan memberikan suatu indikasi bahwa pada komponen pembiayaan Hutang luar negeri ternyata tidak secara langsung memiliki hubungan terhadap pertumbuhan ekonomi. Tetapi hutang luar negeri akan berpengaruh pada pertumbuhan ekonomi melalui tingkat inflasi yang terjadi.

Sejalan dengan adanya pengaruh pembiayaan hutang luar negeri yang meningkat. Sebenarnya terjadinya peningkatan hutang luar negeri yang terjadi dirasa tidak terlalu mengkhawatirkan pengaruhnya terhadap pertumbuhan ekonomi, sungguhpun demikian yang perlu dikhawatirkan adalah ketika hutang luar negeri tersebut akan mendorong terjadinya desakan peningkatan inflasi. Oleh sebab itu dalam manajemen hutang luar negeri setidaknya akan melihat suatu koridor di mana ketika terjadi dorongan Inflasi (cost push inflation). Selama hutang luar negeri yang dilakukan pemerintah tidak mempunyai pengaruh terhadap desakan peningkatan tingkat inflasi yang terjadi, maka berapapun hutang yang dilakukan pemerintah 
untuk menutup pembiayaan defisit anggarannya, tidak perlu dikhawatirkan.

\section{Hasil Interpretasi di Luar Keterkaitan Aspek Pembiayaan}

Di luar dari keterkaitan persoalan pembiayaan terdapat aspek moneter yang perlu diperhatikan yakni:

(1) Melalui alur suku bunga lag SBI satu periode lsbi(-1) yang langsung berpengaruh pada pertumbuhan ekonomi (ly)

(2) Melalui alur suku bunga lag SBI satu periode yang memiliki hubungan dengan inflasi (linf) yang terjadi, dan dari kaitan tingkat inflasi kemudian berhubungan dengan pertumbuhan ekonomi (ly)

(3) Melalui alur suku bunga lag SBI satu periode yang memiliki hubungan jumlah uang beredar (ljub) dan JUB kemudian memiliki hubungan dengan pertumbuhan ekonomi (ly)

(4) Melalui alur suku bunga lag SBI satu periode yang kemudian berhubungan dengan SBI saat ini, kemudian dari SBI akan memiliki hubungan dengan tingkat inflasi (linf), dan baru kemudian akan mempengaruhi pertumbuhan ekonomi (ly)

(5) Kebijakan moneter bekerja dengan mengubah tingkat bunga. Efek penurunan tingkat su$\mathrm{ku}$ bunga mungkin tidak dengan sendirinya dirasakan hingga jangka waktu cukup lama. Kebijakan moneter ekspansif adalah merupakan salah satu kebijakan yang dilakukan untuk meningkatkan penawaran uang atau menurunkan tingkat bunga. Maka adanya penurunan tingkat bunga tahun lalu yaitu tingkat suku bunga lag satu periode, mengakibatkan terjadinya kenaikan pertumbuhan ekonomi.

Kebijakan moneter yang dilakukan oleh otoritas moneter dalam tingkat bunga tersebut selanjutnya, akan mempengaruhi pergerakan sektor riil, di mana apabila sektor riil tumbuh maka akan mengakibatkan terjadinya peningkatan investasi. Dengan adanya peningkatan investasi yang berlangsung, maka akan memberikan dampak bagi peningkatan pertumbuhan ekonomi. Sungguhpun demikian seandainya investasi yang direncanakan memiliki ketergantungan pada tingkat bunga, maka apabila terjadi kenaikan pada tingkat bunga yang lebih tinggi akan mengakibatkan menurunnya investasi yang direncanakan, dan tentunya akan mengurangi pertumbuhan ekonomi. Ini sejalan dengan teori kebijakan moneter dalam pengendalian tingkat bunga, bahwa ketika perekonomian berekspansi, maka Bank Sentral menggunakan operasi pasar terbuka untuk menaikkan tingkat bunga secara perlahan untuk mencoba mencegah perekonomian berekspansi terlalu cepat. Sebaliknya sewaktu perekonomian berkontraksi, Bank Sentral menurunkan tingkat bunga secara perlahan untuk melonggarkan (dan akhirnya menghentikan) kontraksi.

\section{Teridentifikasinya Sumber Pembiayaan yang Paling Cocok bagi Perekonomian Indonesia.}

Hasil analisis studi penelitian yang dilakukan menyangkut penyusunan skenario pemenuhan target pertumbuhan ekonomi yang terjadi memberikan suatu ilustrasi kinerja bagi beberapa indikator makro ekonomi relatip baik dengan trend pencapaian hasil pertumbuhan ekonomi. Dukungan koordinasi yang baik antara kebijakan fiskal dan moneter dapat memberikan stimulus dan menjaga stabilisasi perekonomian. Deskripsi kebijakan fiskal maupun moneter memiliki tujuan untuk memperlancar fleksibilitas dalam pertumbuhan dan lapangan kerja, serta mempertahankan harga stabil mungkin. Oleh sebab itu tujuan stabilitas tidak selalu mudah dicapai karena adanya keterlambatan waktu, atau penundaan tanggapan perekonomian terhadap kebijakan ekonomi makro.

Dalam kebijakan moneter, Bank Sentral mengendalikan tingkat bunga, bukannya penawaran uang. Nilai tingkat bunga yang dipilih akan bergantung pada kondisi perekonomian. Bank Sentral menginginkan pertumbuhan tinggi dan tingkat inflasi rendah, dan Bank Sentral akan cenderung menurunkan tingkat bunga selama periode pertumbuhan rendah dan tingkat inflasi rendah, sebaliknya akan cenderung menaikkan tingkat bunga selama periode pertumbuhan tinggi dan tingkat inflasi tinggi.

Di samping kebijakan moneter, dalam kebijakan ekonomi makro juga terdapat kebijakan fiskal yang merupakan partner kebijak- 
Tabel 5. Skenario Perekonomian dan Pembiayaan Defisit Anggaran

\begin{tabular}{lllcc}
\hline \multicolumn{1}{c}{ Simulasi } & Variabel Simulasi & Variabel Tetap & Pertumbuhan & Inflasi \\
\hline $\begin{array}{l}\text { Base normal*) } \\
\text { Simulasi 1 }\end{array}$ & $\begin{array}{l}\text { Pembiayaan } \\
\text { domestik naik 15\% }\end{array}$ & Lainnya tetap & 217,04 & 10,25 \\
Simulasi 2 & $\begin{array}{l}\text { Pembiayaan Luar } \\
\text { negeri naik 15\% }\end{array}$ & Lainnya tetap & 218,44 & 10,14 \\
Simulasi 3 & $\begin{array}{l}\text { Pembiayaan } \\
(\text { Dn+Ln) naik 15\% }\end{array}$ & Lainnya tetap & 217,04 & 10,22 \\
\hline
\end{tabular}

Sumber: data skenario simulasi diolah dari data sekunder.

*) Kondisi normal adalah ketika tidak terjadi krisis ekonomi

an moneter dalam mengendalikan stabilitas ekonomi dan mendorong pertumbuhan ekonomi. Demikian pula kebijakan fiskal adalah merupakan salah satu kebijakan ekonomi makro untuk mengendalikan stabilisasi perekonomian dan mendorong pertumbuhan ekonomi.

Kebijakan fiskal digunakan untuk mengatur permintaan maupun penawaran agregat melalui komponen dan besaran anggaran belanja untuk kepentingan alokasi, distribusi, dan stabilisasi untuk menggerakkan sektor riil, dengan memperhitungkan besaran defisit dan kemampuan pembiayaan tanpa merusak indikator makro lainnya.

Dalam beberapa tahun terakhir strategi kebijakan fiskal lebih diarahkan untuk melanjutkan dan memantapkan langkah-langkah konsolidasi fiskal dalam mewujudkan anggaran belanja yang sehat dan berkelanjutan (fiscal sustainability), namun masih dapat memberikan ruang untuk stimulus fiskal dalam batasbatas kemampuan keuangan negara.

Jadi garis besar suatu kebijakan fiskal secara umum dalam arah ekspansif yang dicerminkan dari adanya kebijakan defisit, dapat memberikan andil bagi peningkatan pertumbuhan ekonomi. Sedangkan pada sisi moneter akan diupayakan menjaga kestabilan kurs, terpenuhinya target tingkat inflasi yang telah ditentukan, juga mencermati mengendalikan agar tingkat suku bunga relatip terjaga.

Oleh sebab itu simulasi yang dilakukan dalam penelitian, mencoba untuk melihat pemenuhan dalam target pertumbuhan ekonomi dengan berbagai alternatif pengelolaan sumber pembiayaan defisit anggaran. Dari simulasi yang dicoba dilakukan, dengan beberapa alternatif persentase yaitu 15 persen, 20 persen, dan 25 persen dari base-nya, ternyata polanya menunjukkan hasil relatif sama. Sedang penentuan besarnya persentase itu sendiri tidak ada standar baku yang menjadi rujukan, karena yang dipersoalkan bukanlah skenario 15 persen atau 20 persen, dan 25 persen, tetapi yang akan dilihat apakah ada perbedaan ketika pembiayaan dihasilkan dari sumber yang berlainan yaitu bagaimana apabila pembiayaan dilakukan dengan melalui domestik, hutang luar negeri atau kedua-duanya secara bersama-sama. Dengan demikian, peneliti berkeyakinan bahwa untuk menentukan pilihan 15 persen adalah relevan berdasar dan cukup ideal dalam penentuan besarnya persentase tersebut. Dengan demikian simulasi yang dilakukan adalah sebagai berikut

Simulasi 1 apabila dn naik 15 persen, sedangkan yang lainnya tetap, Simulasi 2 apabila HIn naik 15 persen, sedangkan yang lainnya tetap, Simulasi 3 apabila pembiayaan domestik dan luar negeri sama-sama dinaikkan 15 persen, sedang SBI(-1) tetap.

Beberapa skenario pemenuhan target pertumbuhan yang dilakukan memiliki kelebihan serta kelemahannya masing-masing. Sungguhpun demikian, yang nampaknya cukup baik dalam kondisi perekonomian normal di simulasi 1 (lihat Tabel 5). Dengan menaikkan komponen pembiayaan domestik sebesar 15 persen, maka pertumbuhan ekonomi naik relatif antara 1,40 persen, sedang tingkat inflasi turun antara 0,11 persen. demikian juga tingkat suku bunga 
Tabel 6. Implikasi dari simulasi Skenario Perekonomian dan Pembiayaan Defisit Anggaran

\begin{tabular}{lllcc}
\hline Simulasi & Variabel Simulasi & Variabel Tetap & Pertumbuhan & Inflasi \\
\hline Base & SBI(-1) naik & & 216,48 & 6,81 \\
Tidak normal ${ }^{* *}$ & & & 216,39 & 6,78 \\
Simulasi 1 & Pembiayaan domestik naik 15\% & Lainnya tetap & 216,56 & 6,80 \\
Simulasi 2 & Pembiayaan Luar negeri naik 15\% & Lainnya tetap & 216,89 & 6,83 \\
Simulasi 3 & Pembiayaan (Dn+Ln) naik 15\% & Lainnya tetap &
\end{tabular}

Sumber: data skenario simulasi diolah dari data sekunder

**) kondisi tidak normal, adalah kondisi ketika terjadi krisis ekonomi

relatif tetap sebesar 13,75 persen.

Dalam kondisi normal, maka pembiayaan domestik akan lebih menguntungkan, yang berarti terjadi adanya ekspansi, tetapi tidak menimbulkan inflasi. Sedang pembiayaan luar negeri cenderung terjadi inflasi, dan menimbulkan kontraksi ekonomi.

Tetapi pada suatu kondisi perekonomian yang tidak normal (apabila terjadi krisis ekonomi), dalam keadaan di mana melalui komponen tingkat suku bunga tahun lalu akan memberikan alternatif pilihan simulasi, yaitu jika tingkat suku bunga tahun lalu dinaikkan sebesar 15 persen, sedangkan pembiayaan luar negeri juga dinaikkan 15 persen maka pertumbuhan ekonomi akan tetap dibandingkan dengan PDB base sebesar 216,48, sedangkan tingkat inflasi akan turun dari 6,81 persen menjadi 6,80 persen.

Implikasi lebih jauh berarti perekonomian akan lebih baik apabila berada pada simulasi 2 walaupun pertumbuhan cenderung meningkat, tetapi inflasi cenderung turun hanya sebesar 0,01 persen (Lihat Tabel 6). Dalam kondisi situasi ekonomi tidak nornal pilihan pembiayaan yang paling baik mestinya di saat inflasinya cenderung turun, sungguhpun dari sisi pertumbuhannya tidak harus meningkat. Dalam kondisi situasi ekonomi yang tidak nornal seperti ini maka simulasi 2 merupakan pilihan yang terbaik dibandingkan simulasi 1.

\section{Kontribusi Penelitian}

Berdasarkan hasil analisis dan pembahasan terhadap fakta-fakta empiris dapat memberikan kontribusi teoritis maupun praktis lebih lanjut terkait dengan analisis pembiayaan defisit anggaran di Indonesia. Pembiayaan Anggaran dalam penelitian ini didekati melalui pembiayaan domestik (dalam negeri) dan Pembiayaan pin- jaman atau hutang luar negeri.

Pembiayaan domestik memberikan hasil positif signifikan, yang artinya pembiayaan domestik akan meningkatkan pertumbuhan melalui belanja pemerintah terutama belanja pemerintah yang produktif, akan mendorong pertumbuhan ekonomi dan tidak mendorong terjadinya inflasi.

Sedangkan dari pembiayaan hutang luar negeri, mengindikasikan apabila dilakukan pinjaman melalui hutang luar negeri, akan memiliki dampak terhadap peningkatan inflasi. Dengan naiknya inflasi, akan mengakibatkan pertumbuhan berkurang. Selama hutang luar negeri tidak mengakibatkan terjadinya dorongan inflasi maka berapapun hutang luar negeri yang dibutuhkan untuk menutup pembiayaan defisit anggaran tidak perlu dicemaskan.

\section{SIMPULAN}

Berdasarkan hasil analisis di atas dapat disimpulkan sebagai berikut:

Pertama, Adanya sumber pembiayaan defisit dengan cara yang berbeda, ternyata menghasilkan kinerja makroekonomi yang berbeda pula. Oleh karena itu, pemilihan sumber pembiayaan menjadi sangat penting. Beberapa literatur hanya sedikit memberikan informasi, karena studinya lebih pada dampak defisit anggaran dan tidak fokus pada dampak setiap jenis sumber pembiayaan defisit. Dengan demikian, studi ini tidak hanya memberikan kontribusi pada perekonomian Indonesia, tetapi juga memperkaya referensi bahwa jenis pembiayaan memiliki implikasi penting bagi suatu perekonomian. Kedua, ditemukan bahwa pembiayaan defisit anggaran melalui sumber pembiayaan 
domestik memberikan hasil yang lebih baik dari pada sumber pembiayaan luar negeri. Dampak pembiayaan melalui sumber pembiayaan domestik mampu menghasilkan pertumbuhan tanpa diikuti oleh meningkatnya inflasi. Sedangkan kalau yang digunakan adalah sumber pembiayaan luar negeri, pertumbuhan ekonomi yang terjadi dibarengi dengan relatif tingginya inflasi. Ketiga, salah satu penjelasan temuan diatas adalah bahwa pembiayaan melalui hutang domestik tidak menyebabkan terjadinya pelarian sumberdaya ekonomi ke luar negeri. Maksudnya bunga atau return dari hutang domestik masih mungkin dapat dinikmati dan berputar di dalam negeri sehingga tetap akan memberikan kontribusi pada perekonomian dalam negeri. Keempat, ketika perekonomian tidak normal (dalam kondisi krisis) yang ditandai oleh tingginya tingkat bunga SBI, maka masing-masing sumber pembiayaan memiliki dampak yang spesifik. Ketika yang dipilih adalah sumber pembiayaan domestik, maka pertumbuhan ekonomi akan negatif sebesar 0,09 tetapi inflasi turun sebesar 0,03. Ketika yang dipilih adalah sumber pembiayaan luar negeri, maka inflasi turun sedikit sebesar 0,01 persen tetapi pertumbuhan ekonominya positif dalam arti meningkat sebesar 0,08 persen. Sedangkan ketika menggunakan sumber pembiayaan dalam negeri dan luar negeri secara bersama, maka pertumbuhan ekonomi sangat tinggi yaitu sebesar 0,41 , tetapi inflasinya cenderung meningkat sebesar 0,02 persen.

Saran. Beberapa saran yang perlu diberikan untuk mengimplementasikan hasil studi penelitian ini antara lain: (1) Apabila ingin melakukan pembiayaan dalam negeri atau domestik seyogyanya melalui penjualan Obligasi atau Surat Hutang Negara, sedangkan untuk masa yang akan datang Surat Hutang Negara tersebut diharapkan akan terus dikembangkan. (2) Apabila ingin melakukan pembiayaan hutang luar negeri, yang perlu diperhatikan adalah aspek untuk tetap memberikan implikasi terhadap pertumbuhan ekonomi tetapi tidak mengakibatkan dampak terjadinya dorongan inflasi. Sungguhpun demikian pembiayaan Hutang Luar Negeri harus dilakukan secara hati-hati (prudent). (3) Apabila akan melakukan pilihan yang paling baik, maka perlu diperhatikan agar diusahakan tetap terjadi kenaikan pertumbuhan ekonomi dengan disertai penurunan tingkat inflasi.

\section{DAFTAR PUSTAKA}

Abimanyu, Anggito. 2005. Kebijakan Fiskal dan Efiektivitas Stimulus Fiskal di Indonesia, Aplikasi Model Makro-Modfi dan CGEIndorani, Indonesian Economic Journal, ISEI, no.1 Juni 2005: 1-36.

Adji, Arti. 1995. Is Public Debt Neutral? Evidence For Indonesia, Journal Ekonomi dan Bisnis Indonesia (JEBI), September 1995, 2132.

Ahonen, Pertti. 2007. Unconscious Aesthetics in Financial Public Management: Political Science on a Ubiquitous, Deceivingly Unintereting Topic, Political Science on a Ubiquitous, Halduskultuur, Vol.8 pp.3868.

Albu, Lucian-Liviu and Pelinescu, Elena. 2000. Sustainability of Public Debt: A Theoritical and Empirical Investigation, MPRA, paper No.14364. Online http://mpra.ub unimuenchen.de/14364/.

Batini, Nicollate and Andrew G Haldane. 1998. Forward-looking Rules for Monetary Policy. London:Bank of England.

Batini, Nicollate and Andrew G Haldan. 1999. Forward-looking Rules for Monetary Policy, The National Bureau of Economic Research, University of Chicago Press.

Buiter, Willem H, Torsten Persson, Patrick Minford. 1985. A guide to Public Sector debt and Deficits, Economic Policy, Vol.1 No.1, Centre for Economic Policy Research, Blackwell Publishing, Printed in Great Britain.

Chantrasmi, Mary. 1990. Government Budget Deficit, Crowding-out and Inflation in Thailand 1970-1986, Phd Dissertation, University of Hawaii. 
Coe, Patrick J., M Hashem Pesaran, Shaun P Vahey. 2003. Scope for Cost Minimization in Public Debt management: The case of the UK, CWPE 0338.

Dadkhah Kamran. 2009. The Evolution of Macroeconomic Theory and Policy. London New York: Springer Dordrecht Heidelberg.

Departemen Keuangan Republik Indonesia. 2005. Model Referensi MODFI Ekonomi Makro Departemen Keuangan, Oktober 2004, Jakarta.

Departemen Keuangan Republik Indonesia. 2009. Jurnal Keuangan Negara, Volume 1 Edisi 1 tahun 2009, Jakarta: Badan Kebijakan Fiskal Departemen Kuangan.

El Mahdi Abda Yahia. 2008. Budget Analysis For Pro-Poor Spending. Sudan: UNDP.

Greene, William H. 2003. Econometric Analysis. Fifth edition. New Jersey: Upper Saddle River.

Grier Kevin, and Haichun Kamu. 2007. Twin Sons of Different Mothers: The Long and the Short of the Twin Deficits Debate. University of Oklahoma.

Gujarati, Damodar N,. 2003. Basic Econometrics, Fourth Edition, International Edition, New York: McGraw Hill.

Hakim, Lukman. 2006. Pengaruh Hutang Luar Negeri, Kebijakan Fiskal terhadap Konsumsi Masyarakat dalam Paradigma Ricardian Equivalence 1990-2004, Penelitian dibiayai Dirjen DIKTI, 1 Februari 2006. Fakultas Ekonomi Universitas Sebelas Maret.

Haldane, Andrew.G, Nicolette Battini. 1998. Forward Looking Rules For Monetary Policy, Working paper 6543, National Bureau of Economic Reseach, Cambridge.

Hossain, Akhtar, and Anis Chowdhury. 1998. Open Economy Macroeconomics for Developing Countries, Northamton Massachusetts USA: Edward Elgar Publishing Limited.

Kapopoulos, Panayotis. 2004. When can Fiscal Consolidation be Expansionary? Evidence from a Small Open Economy, Journal of Policy Modeling, 26 (2004) 1031-1043, North Holland.

Kendrick David A, Hans A Amman. 2010. A Taylor Rules for Fiscal Policy?. Submitted to Conference of SCE, May 29

Kim, Wansup. 2003. Review of Ricardian Equivalence: Theoretical and Empirical Studies; Literature Synthesis.

Kunarjo. 2001. Defisit Anggaran Negara. Majalah Perencanaan Pembangunan, Edisi. 23 Tahun 2001.

Labonte, Marc. 2010. The Size and Role of Government: Economics Issues. Congressional Research Service, 7-5700, June 14, 2010.

Lestari, Sri. 2003. Analisis Pengaruh Pengeluaran Pemerintah dan Penawaran Uang terhadap Pertumbuhan Ekonomi Indonesia Tahun 1975-2000, Karya Tulis Ilmiah FE UMS, Surakarta.

Mankiw N., Gregory. 2007. Macroeconomics Theory. New York: Worth Publishers.

Maryatmo, R,. 2004. Dampak Moneter Kebijakan Defisit Anggaran Pemerintah dan Peranan Asa Nalar dalam Simulasi Model Makro-Ekonomi Indonesia (1983:1-2002: 4), Buletin Ekonomi Moneter Perbankan, September 2004.

Saad, Wadad, Kamel Kalakech. 2009. The Impact of Budget Deficits on Money Demand: Evidence from Lebanon, Middle Eastern Finance and Economics, Issue.3, Euro Journals Publishing Inc.

Saleh, Ali Salman. 2003. The Budget Deficit and Economic Performance: A Survey. Economics Working Paper Series, University of Wollongong, Toronto: Harcourt Brace Jovanovich, September 2003.

Saleh, Ali Salman. 2004. Public Sector Deficits and Macroeconomics Performance in Lebanon. Ph.D Dissertation, University of Wollongong Australia, 2004. 
Sikki, Nawir. 2009. Kebijakan Pembiayaan - Anggaran Pembangunan dalam Rencana Kerja Pemerintah Tahun 2009. Sakernas Jari.

Singh, Balwant. 2005. A Forecasting and Policy Simulation Oriented Small Macro-Model for the Indian Economy. Journal of Policy Modeling, 27 (2005), 1025-1049. El-sevier.

Soebagiyo, Daryono. 2002. Deficit Spending dan Pengaruhnya terhadap Pendapatan Nasional dan Inflasi, Jurnal Ekonomi Pembangunan 2002 (vol 3 no 1, 46-54), BPPE - FE UMS, Surakarta.

Soebagiyo, Daryono. 2005. Defisit Spending and Economics Growth in Indonesia. International Seminar: Empowering Economy and Business in Free Trade Era. Universiti Kebangsaan Malaysia and Muhammadiyah Unversity of Surakarta. Surakarta.

Stiglitz, Joseph. 2004. The Parties' Flip-Flops on Deficit Spending: Economics or Politics?, The Economists' Voice, Volume 1, Issue. 1 Article.2, The Barkeley Electronic Press (Bepress),http//www.bepress.com/ev

Tanuwidjaja, Enrico, Choy Keen Meng. 2005. Central Bank Credibility and Monetary Policy: Evidence from Small Scale Macroeconomics Models in Indonesia, SCAPE Working Paper Series Paper No. 2005/14 Nov 2005 Singapore Centre for Applied and Policy Economics, National University of Singapore.
Tanuwidjaja, Enrico, Choy Keen Meng. 2006. Central Bank Credibility and Monetary Policy in Indonesia. Journal of Policy Modeling 28 (2006) 1011-1022, Elsevier.

Vernengo, Matias. 2005. Technology, Finance, and Dependency: Latin American Radical Political Economy in Retrospect, Review of Radical Political Economics, Volume 38, No.4, Fall 2006, pp.551-568.

Waluyo, Joko. 2004. Model Ekonomi Makro Defisit Anggaran Pemerintah Pusat Indonesia Tahun 1979-2003, Jurnal Ekonomi Pembangunan UPN, Jogjakarta.

Wicaksono, Gunawan, Ariantoro, Rheina A. Sari. 2002. Penghitungan Data Stok Kapital dengan Metode Perpetual Inventory (PIM): Suatu Upaya Penyediaan Data Stok Kapital untuk Penghitungan Potensial Output dengan Pendekatan Fungsi Produksi. Buletin Ekonomi Moneter dan Perbankan, Bank Indonesia, September. 5(2).

Widodo, Budiarso Teguh. 2006. Implikasi Pembiayaan Defisit APBN terhadap Kesinambungan Fiscal (Fiscal Sustainability): (studi kasus: APBN Indonesia). Tesis S2 Tidak dipublikasikan, Deskripsi Dokumen Perpustakaan UI, Jakarta. 